\title{
WATER-QUALITY ASSESSMENT OF THE CARSON RIVER GROUND-WATER BASIN, NEVADA AND CALIFORNIA: PROJECT DESCRIPTION
}

By Alan H. Welch and Russell W. Plume

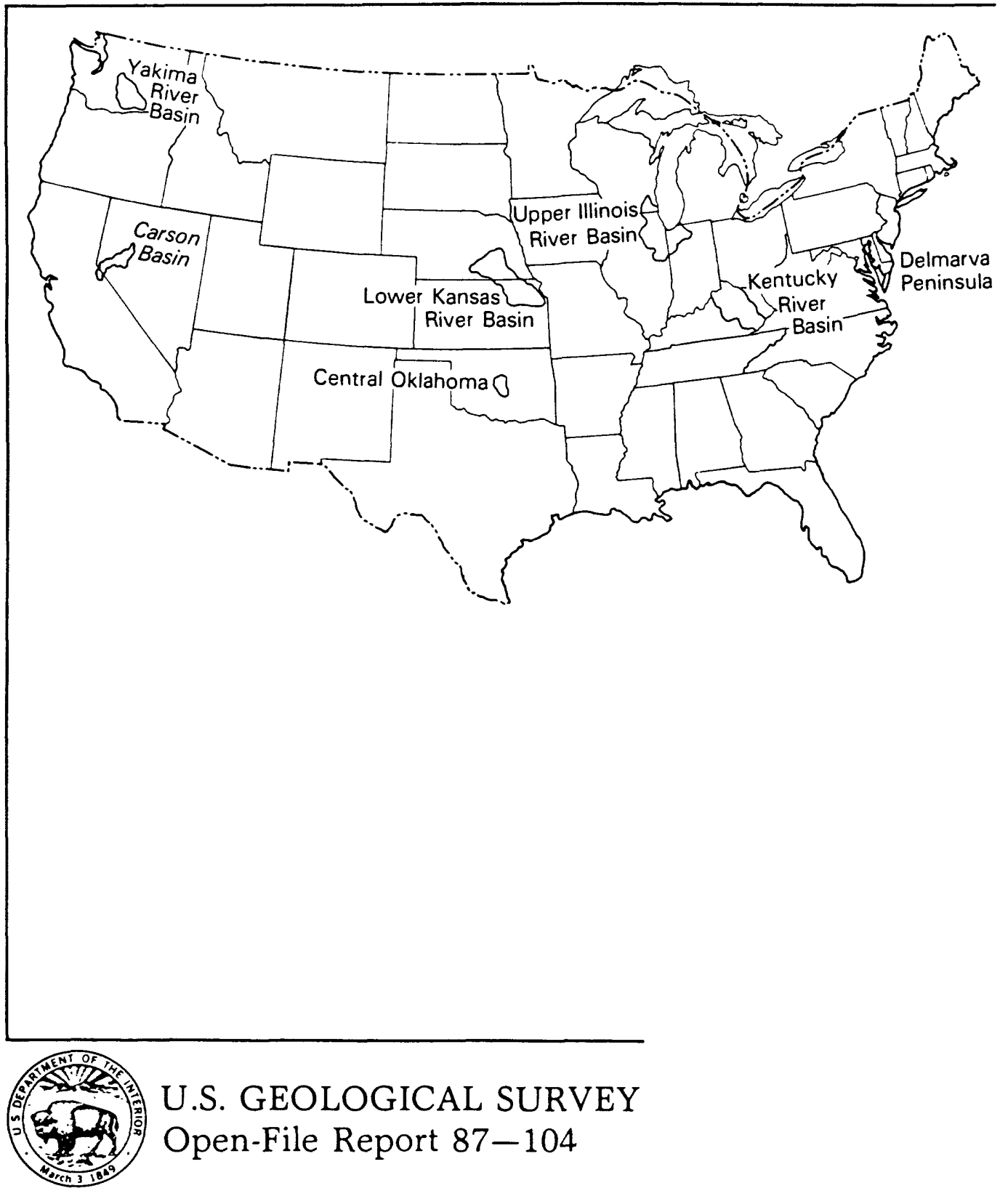




\title{
DEPARTMENT OF THE INTERIOR \\ DONALD PAUL HODEL, Secretary
}

\author{
U.S. GEOLOGICAL SURVEY
}

Dallas L. Peck, Director

For additional information write to:

Copies of this report can be purchased from:

District Chief

U.S. Geological Survey

Books and Open-File Reports

Water Resources Division

Section

U.S. Geological Survey

Room 224, Federal Building

Federal Center, Box 25425

705 North Plaza Street

Carson City, Nevada 89701 


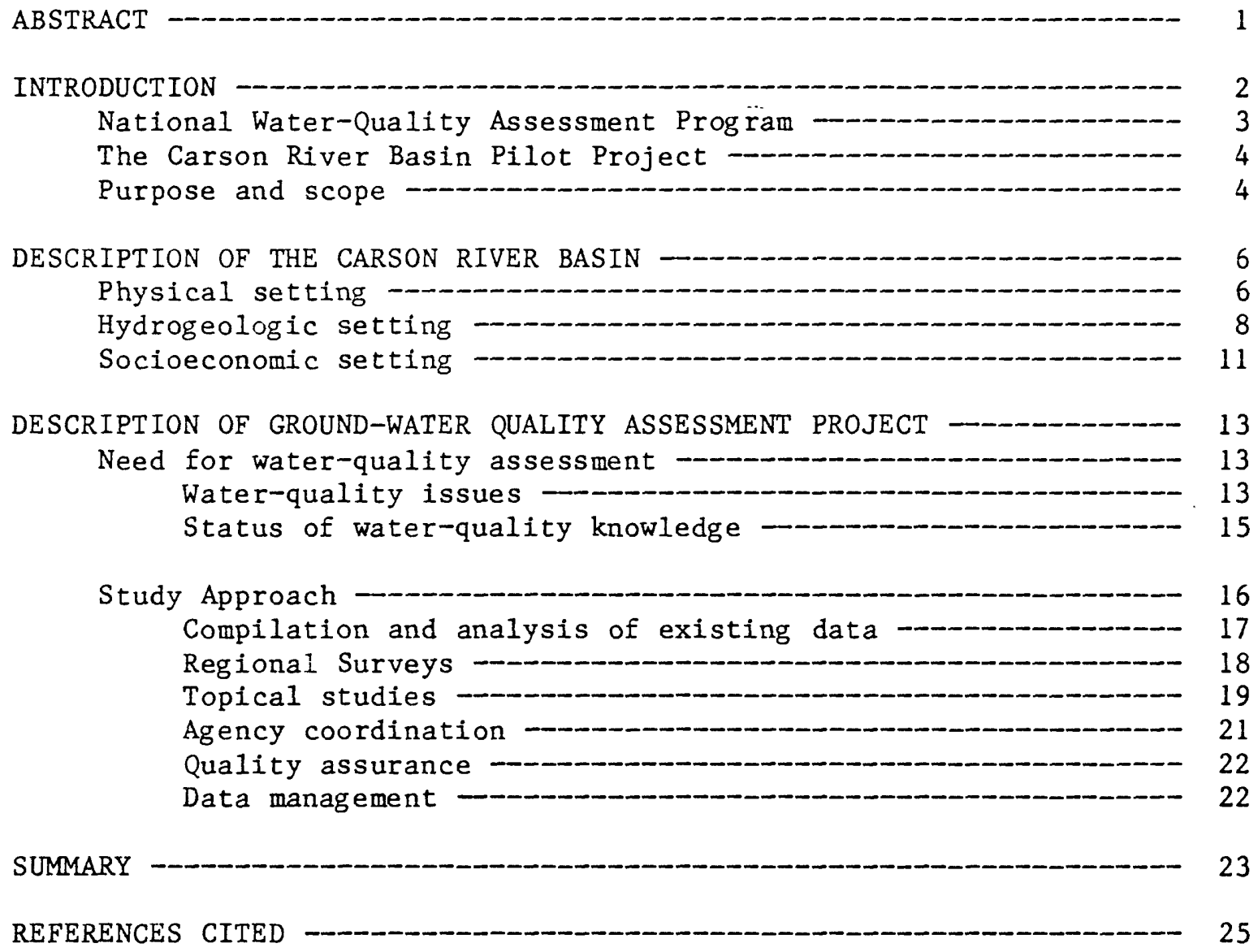

ILLUSTRATIONS

Figures 1-3. Maps showing:

1. Location of study area 5

2. Areal distribution of hydrographic areas - 7

3. Generalized hydrogeology 9

4. Graph showing total population for Counties in the study area, 1920-85 - 
"Inch-pound" units of measure used in this report may be converted to metric (International System) units by using the following factors:

Multiply

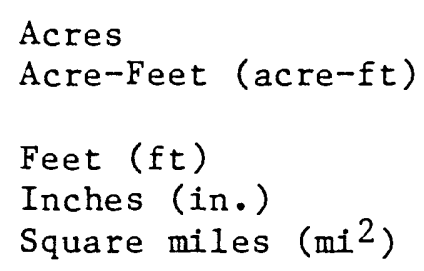

by

$$
0.4047
$$$$
0.001233
$$$$
0.3048
$$$$
25.40
$$

2.590
To obtain

Square hectometers $\left(\mathrm{hm}^{2}\right)$

Cubic hectometers $\left(\mathrm{hm}^{3}\right)$

Meters (m)

Millimeters (mm)

Square kilometers $\left(\mathrm{km}^{2}\right)$

\section{ALTITUDE DATUM}

In this report, "sea level" refers to the National Geodetic Vertical Datum of 1929 (NGVD of 1929), which is derived from a general adjustment of the first-order leveling networks of both the United States and Canada. 
WATER-QUALITY ASSESSMENT OF THE
CARSON RIVER GROUND-WATER BASIN,

NEVADA AND CALIFORNIA:

PROJECT DESCRIPTION

By Alan H. Welch and Russell W. Plume

\begin{abstract}
In April 1986, the U.S. Geological Survey began a pilot program to assess the quality of the Nation's surface-water and ground-water resources. This program, called the National Water-Quality Assessment (NAWQA) program, is designed to acquire and interpret information about a wide range of water-quality issues. The emphasis of the program will be on characterizing regional water quality with respect to a broad range of water-quality constituents. The program is in its early stages and consists of four surface-water and three ground-water pilot projects. One of these projects is a study of regional groundwater quality in the Carson River basin of western Nevada and eastern California. This report describes the objectives of the Carson River basin NAWQA project in the context of the national program, the study area and its associated water-quality issues, and a proposed study approach.
\end{abstract}

The project will develop and test methods for assessment of ground water quality. The objectives of the Carson River basin NAWQA project are to: (1) investigate regional ground-water quality, particularly with respect to potentially toxic substances, throughout the project area in a manner consistent with the other ground-water pilot studies; (2) describe relations of ground-water quality to land use, hydrogeology, and other pertinent factors; (3) provide a general description of the location, nature, and possible causes of selected widespread water-quality problems in the project area; and (4) develop new techniques for characterizing regional ground-water quality, especially in arid alluvial basins.

The Carson River basin covers 3,980 square miles in eastern California and western Nevada and consists of a headwaters area and six aliuvial valleys that are interconnected by the Carson River. Ground water is stored primarily in deposits of clay, silt, sand, and gravel that have accumulated in the deep bedrock basin that underlies each valley. 
Land and water use in the Carson River basin is rapidly changing; water-quality issues are related principally to concern over potential contamination of drinking-water supplies and rapid urban, suburban, and industrial growth. Avallable data may not be sufficient for characterizing the quality of ground water in the basin. Additional information needed to accomplish the project objectives are: (1) reliable and detailed water-quality data that address the principal water-quality concerns in the basin; (2) hydrogeologic data, including soil and aquifer-material chemistry and physical properties; and (3) current and historic land-use data.

There will be three major phases of the Carson River basin project. The first will consist of compilation and analysis of existing data. The second phase will consist of a regional waterquality survey that will produce a consistent set of data that can be used to ( 1 ) define regional quality of ground water within the Carson River basin, and (2) compare that water quality with other aquifers in the Nation. The third phase will include topical studies that will define ground-water quality in the Carson River basin with respect to certain constituents, either basin wide or within specific areas of concern. The topical studies will address, in more detail, some of the principal water-quality issues in the basin.

\section{INTRODUCTION}

Public awareness of the importance of water quality has increased greatly over the last 20 years; in response, Congress and State and local legislative bodies have enacted wide-ranging pollution-control legislation. This commitment to pollution abatement has been augmented by administrative regulations and the efforts of industry. As a result, the quality of many of the Nation's streams has improved despite increases in industrial activity and population (Association of State and Interstate Water Pollution Control Administrators, 1984). Most of this improvement, however, has been the result of controlling point-source pollution. Ground- and surface-water pollution from nonpoint sources, acid precipitation, and the disposal of hazardous waste will be more difficult problems to solve.

The existing body of information on toxic substances is largely site specific and is derived mainly from mandated monitoring of waters near wastedisposal sites, industrial and municipal discharges, and landfills. A better understanding of the regional distribution of contaminants is needed to provide a more representative assessment of the quality of the Nation's water resources. 


\section{National Water-Quality Assessment Program}

To address this need, the U.S. Geological Survey has initiated a program for data acquisition and interpretation to assess the quality of the Nation's surface- and ground-water resources. The program is known as the National Water-Quality Assessment (NAWQA) program. The long-term goals of the NAWQA program are to: (1) provide a nationally consistent description of the current status of water quality for a major part of the Nation's water resources; (2) where possible, define trends in water quality that have occurred over recent decades and provide a baseline for evaluating future trends; and (3) identify and describe water quality in relation to natural factors and human activities.

The NAWQA program is organized into study units on the basis of known hydrologic systems. For ground water, the study units are large parts of aquifers or aquifer systems, and for surface water the study units are watersheds or parts of watersheds. The study units are large, involving thousands of square miles for ground-water projects and hundreds of miles of stream reaches for surface-water projects.

Because the NAWQA program is national in scope, there will be common approaches, methods, and reporting procedures among the study units. The national scope is critical to assuring consistent and comparable information, which can be integrated and analyzed in a national context. Each project, however, will be designed to investigate the water-quality problems of the individual study unit. Thus, in the design of the NAWQA program, the projects will consider the unique hydrogeologic and geochemical conditions in each study unit.

The NAWQA program began in April 1986 as seven pilot projects: four are surface-water and three are ground-water projects. The locations of the surface-water projects are the Yakima River basin in Washington; the lower Kansas River basin in Kansas and Nebraska; the upper Illinois River basin in Wisconsin, Illinois, and Indiana; and the Kentucky River basin in Kentucky. The ground-water projects are the Carson River basin aquifers in western Nevada and eastern California; central Oklahoma aquifer system near Oklahoma City, Okla.; and the Delmarva Peninsula aquifers in Delaware, Maryland, and Virginia. Each ground-water project involves an aquifer, or system of related aquifers, of regional extent. The pilot project will test, and modify as necessary, concepts and approaches in preparation for a possible full-scale national water-quality assessment effort, and will provide an opportunity to evaluate the potential benefits and costs of a fully implemented program. This report is the project description for the Carson River basin project. 
The Carson River Basin Pilot Project

The Carson River basin of western Nevada and eastern California (figure 1) was selected for study by the NAWQA program because of competing demands for a limited water supply, a rapidly changing land-use pattern, and the diversity of hydrologic conditions and water-quality problems. Study techniques developed for the diverse range of conditions in the basin and the experience and results obtained should have transfer value throughout much of the arid West, particularly in other alluvial basin systems.

The objectives of the Carson River basin NAWQA project are to: (1) investigate regional ground-water quality, particularly with respect to potentially toxic substances, in a manner consistent with the other ground-water pilot studies; (2) describe relations of ground-water quality to land use, hydrogeology, and other pertinent factors; (3) provide a general description of the location, nature, and possible causes of selected widespread water-quality problems in the project area; and (4) develop new techniques for characterizing regional ground-water quality, especially in arid alluvial basins.

\section{Purpose and Scope}

The purposes of this report are to describe: (1) The goals of the NAWQA program, particularly with regard to the Carson River basin NAWQA project; (2) the project area and its associated ground-water quality issues; (3) the need for an assessment of ground-water quality in the Carson River basin; and (4) a study approach for the Carson River basin NAWQA. The report presents a description of the planned project; as a pilot project, specific approaches to individual problems may well evolve in the course of the project and other approaches that have not yet been anticipated may be used. 


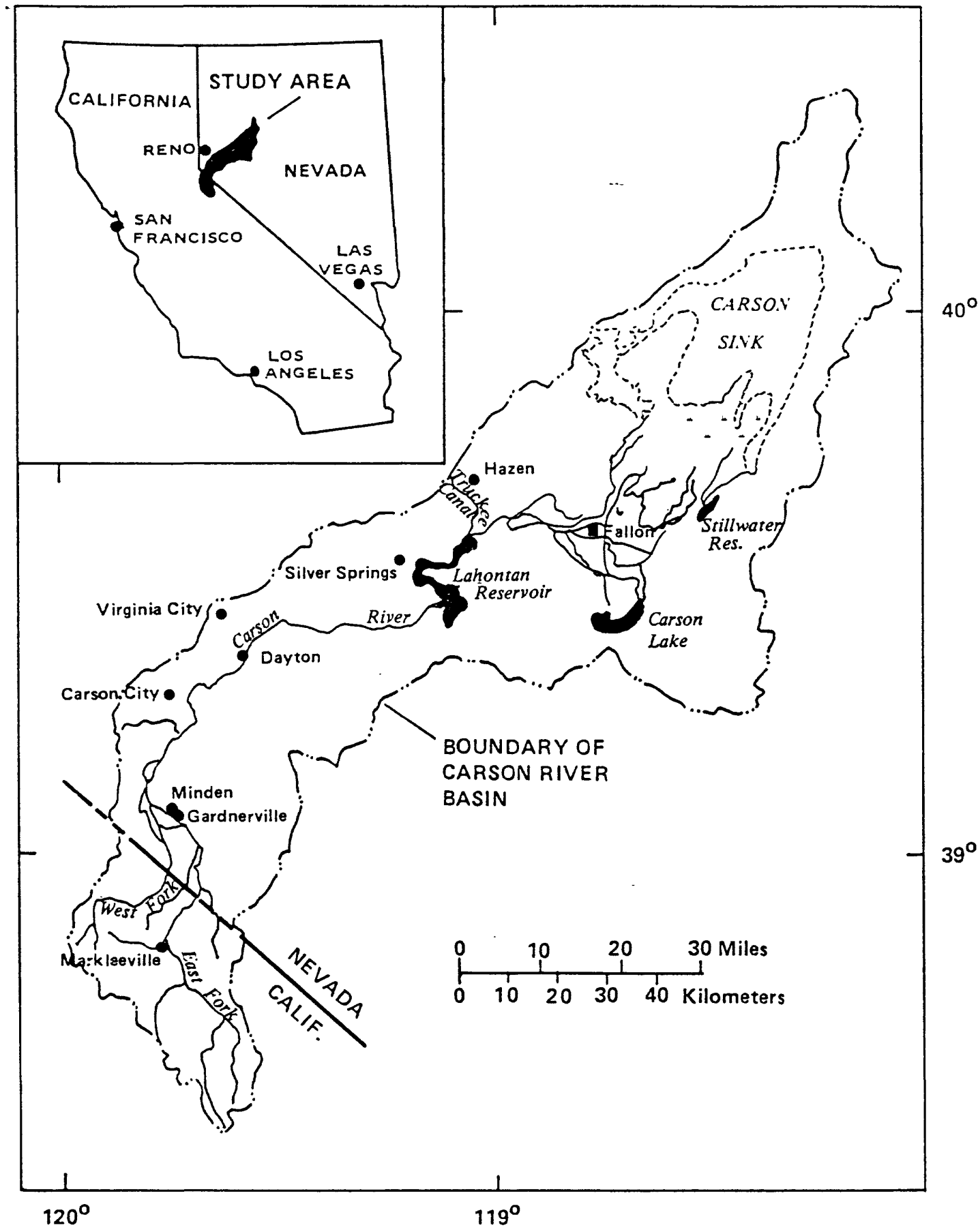

FIGURE 1.--Location of study area. 


\section{DESCRIPTION OF THE CARSON RIVER BASIN}

\section{Physical Setting}

The Carson River basin covers an area of $3,980 \mathrm{mi}^{2}$ in parts of the western Great Basin and eastern Sierra Nevada. The project area is located mostly in western Nevada but includes a small part of eastern California (figure 1). For the purposes of this study, the Carson River basin is subdivided into seven hydrographic areas: the basins of the East and West Forks of the Carson River draining the mountainous headwaters area in the Sierra Nevada (hereafter referred to as "Headwaters Area"), and six major alluvial valleys that are interconnected by the Carson River. The six valleys, in downstream order, are Carson Valley, Eagle Valley, Carson Plains, Stagecoach Valley, Churchill Valley, and the Carson Desert (figure 2).

With two exceptions, the boundaries of the six alluvial valleys as defined for this study conform to hydrographic areas in Nevada (Rush, 1968) that are used by the Nevada State Engineer for purposes of managing and regulating water resources in the State. One exception is Carson Valley which, as used in this study and defined by Brown and others (1986, pages 12 and 23), includes a small area of eastern California; the Nevada State Engineer has administratively selected the State line as the southwestern boundary for the Carson Valley area (Nevada Hydrographic Area 105). The other exception is that the areas designated as Carson Plains and Stagecoach Valley in this report are subunits of the Dayton Valley area (Nevada Hydrographic Area 103) as currently recognized by the Nevada State Engineer. The parts of the Headwaters Area and Carson Valley within California correspond with the Carson-Walker Statewide Planning Study Area used by the California Department of Water Resources for water planning and management.

The valleys of the Carson River basin generally are flat-bottomed and surrounded by steeply rising high mountains. Altitudes of valley floors range from about 3,800 feet in the Carson Desert to nearly 5,000 feet in Carson Valley, whereas altitudes of adjacent mountains are 9,000 to 11,000 feet in Carson and Eagle Valleys and 6,000 to 8,700 feet in the Carson Plains, Stagecoach and Churchill Valleys, and Carson Desert.

The valleys in the Carson River basin have similar types of physiographic features, although the extent of these features can differ markedly among valleys. The major features are mountains, alluvial fans, valley lowlands, and the Carson River flood plain. Alluvial fans extend from the mountain front along valley margins toward the center of each valley. In some places, they merge with valley lowlands and in others they are truncated by the flood plain of the Carson River. The width of the flood plain ranges from less than 1 mile in Carson Plains and Stagecoach Valley to several miles in parts of Carson Valley. The lowlands of Stagecoach Valley consist, in part, of a playa and in the Carson Desert consist of a large area of marshes, shallow lakes, and salt flats. 


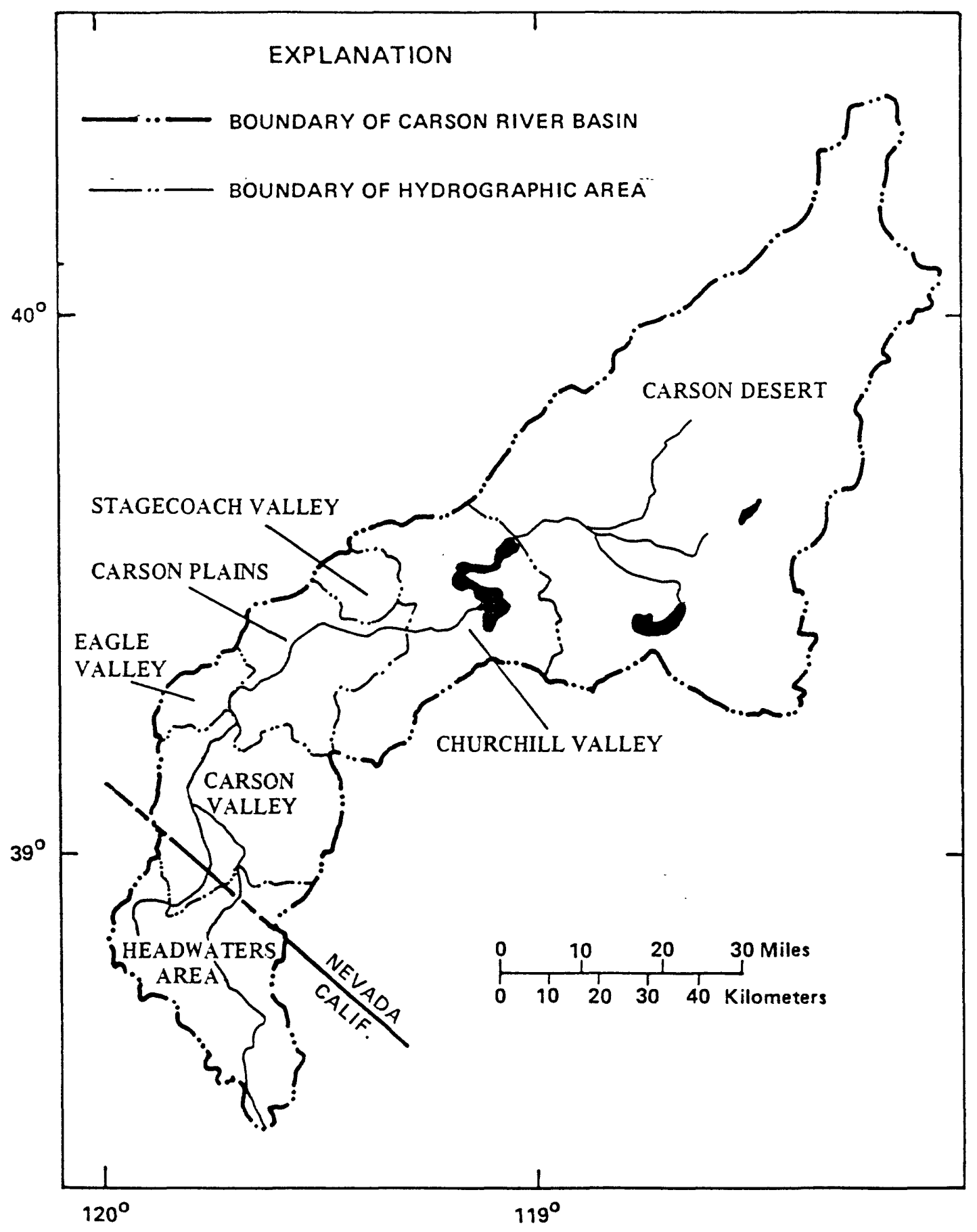

FIGURE 2.--Areal distribution of hydrographic areas. 
The major hydrographic features of the Carson River basin, some of which are shown in figures 1 and 2, are: (1) the East and West Forks of the Carson River in the Headwaters Area; (2) a network of ditches, drains, sloughs, and channels of the Carson River in Carson Valley; (3) the main stem of the Carson River; (4) Lahontan Reservoir on the lower part of the Carson River; (5) the Truckee Canal which transports water from the Truckee River to Lahontan Reservoir; (6) the extensive system of irrigation ditches and drains of the Newlands Irrigation Project near Fallon; and (7) distributary channels, marshes, salt flats, and shallow intermittent lakes in the Carson Desert which is the terminal sink of the Carson River. Many small tributary streams enter the Carson River from adjacent mountains. Some of these tributaries are perennial in valleys as far downstream as Eagle Valley but are ephemeral beyond.

Most of the flow of the Carson River and its perennial tributaries comes from the spring snowmelt each year. Estimated annual precipitation in the Carson River basin ranges from 20 to 40 inches in the higher parts of the Sierra Nevada to less than 8 inches in the lowlands of valleys downstream from Eagle Valley (Glancy and Katzer, 1975, page 48). Most precipitation falls as winter snow, especially in higher parts of the river basin, although heavy winter rains occur during some years and local thunderstorms occur each summer. In addition to the snowmelt, treated sewage imported from the Lake Tahoe basin is applied to agricultural areas in three places in Carson Valley, and water imported from the Truckee River by way of the Truckee Canal enters the river at Lahontan Reservoir.

\section{Hydrogeologic Setting}

The Carson River basin is underlain by a variety of rocks that can be grouped broadly into two hydrogeologic units (figure 3): consolidated rocks of Middle Triassic to Quaternary age (about 230 million to less than 2 million years) and basin-fill deposits of Tertiary and Quaternary age (about 17 million years to present). Consolidated rocks consist of granitic, volcanic, and sedimentary rocks that form the mountainous uplands of the project area and the bedrock that underlies each alluvial valley. These bedrock basins formed as a result of extensional faulting that has occurred throughout the Great Basin during the past 17 million years (Stewart, 1980, page 110). The basins usually are bounded on one or more sides by high-angle normal faults.

Basin-fill deposits began tu accumulace as bedrock basins formed and have continued to do so to the present. The deposits range in thickness from zero at valley margins to more than 5,000 feet in Carson Valley and 8,000 feet or more in the Carson Desert (Maurer, 1985, page 5; Glancy, 1986, page 36$)$. The deposits consist of unconsolidated to partly consolidated clay, silt, sand, gravel, and boulders that are sorted to differing degrees depending on the physiographic setting in which they accumulated. Alluvial fans are usually unsorted to poorly sorted deposits that range in grain size from clay to boulders, although distal ends of fans can be somewhat better sorted than the higher parts of fans along valley margins. 


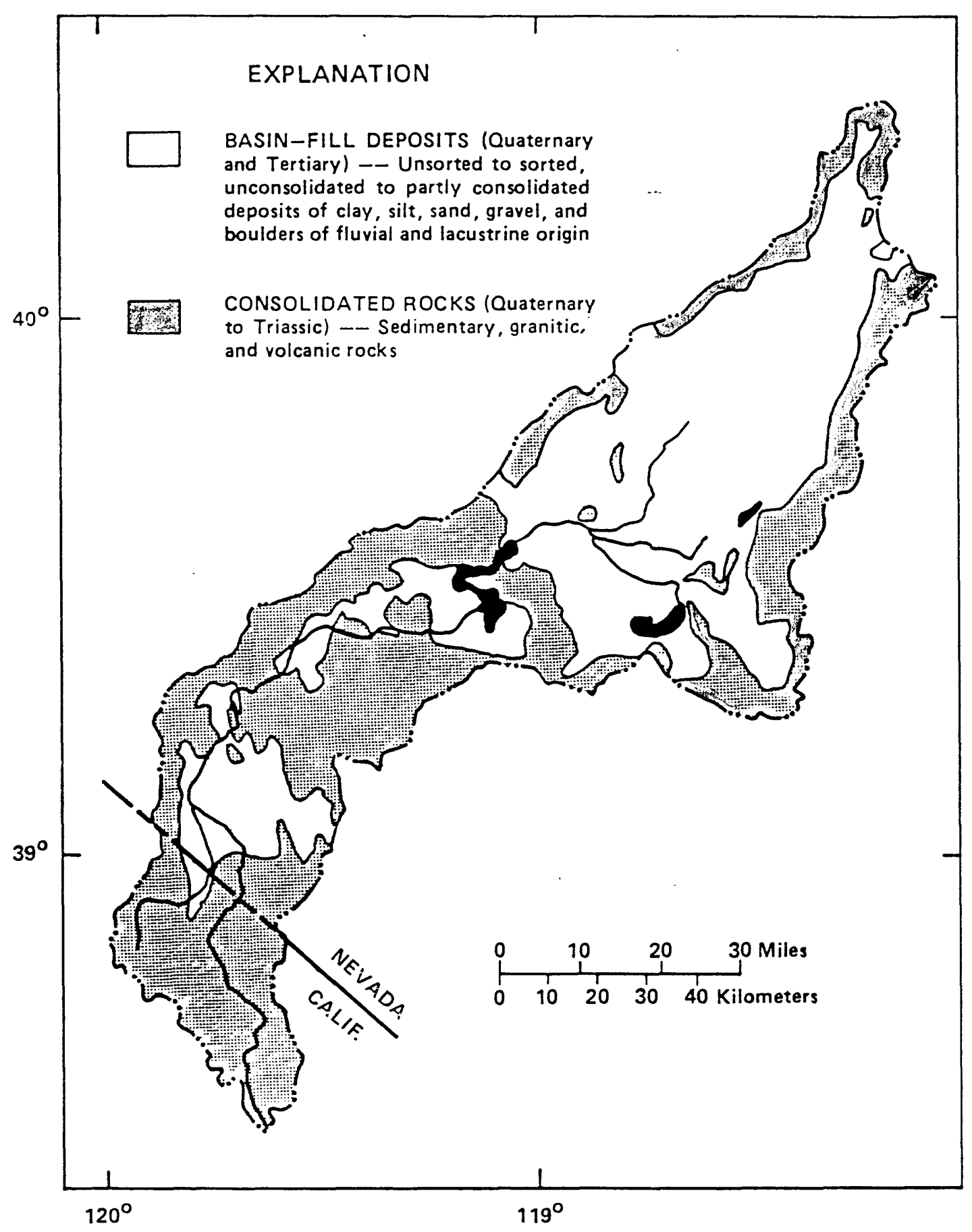

FIGURE 3.--Generalized hydrogeology. Geology modified from Jennings (1977), and Stewart and Carison (1977). 
Valley lowlands are underlain by poorly sorted deposits that range in grain size from clay to gravel. Flood plains are underlain by well-sorted beds of clay, silt, sand, and gravel. In addition, deposits of Pleistocene Lake Lahontan 1 occur in the eastern part of the study area. They consist of surface or near-surface beds of silt and clay deposited on the bottom of the lake and beds that range from clay to gravel deposited in deltas of the Carson River along the edge of the lake. The deposits are found as far west as the Carson Plains and are extensive in the Carson Desert (Morrison, 1964, figure 1).

The major aquifers in the study area are the basin-fill deposits ${ }^{2}$ that underlie each valley of the basin except for a basalt (volcanic rock) aquifer interbedded with basin-fill deposits in the Carson Desert. These aquifers are recharged by snowmelt and precipitation that enter fractured consolidated rocks in mountainous areas and eventually enter the basin fill along valley margins; by infiltration of streamflow from tributaries along and near mountain fronts in Carson and Eagle Valleys; and by infiltration of water from the Carson River. The aquifers discharge by evapotranspiration to crops, native plants, and bare soils; by seepage to the Carson River, irrigation canals, and drains; and by pumpage.

The basin fill in the lowlands of each valley generally contains a shallow water-table aquifer that is in hydraulic continuity with the Carson River. The shallow aquifer commonly is underlain by one or more deeper aquifers that are confined (under artesian pressure) to differing degrees. The extent to which the Carson River and shallow aquifers are in hydraulic continuity differs from valley to valley. The river and a network of irrigation ditches bring recharge to the shallow aquifer in some parts of Carson Valley and act to partially drain the aquifer in other parts of the valley (Maurer, 1986, page 103). The Carson River passes through Eagle Valley along its east side and near Stagecoach Valley along its south side, and acts as a drain toward which ground water moves, although, the aquifer in the southwest part of Stagecoach Valley also receives some recharge from the river (Arteaga, 1982, page 50; James R. Harrill, U.S. Geological Survey, written communication, 1986). Aquifers in the Carson Plains and Churchill Valley are poorly understood and may receive recharge from the river in some areas and discharge to the river in others. Aquifers in the Carson Desert consist of shallow and intermediate basin-fill aquifers, an underlying basalt aquifer, and a deep basin-fill aquifer (Glancy, 1986, pages 57-60). Recharge to these aquifers comes from the Carson River and return flow from extensive agricultural irrigation in the Newlands Project near Fallon.

1 Lake Lahontan was a prehistoric lake that intermittently covered large parts of western Nevada during the past few tens of thousands of years. Lahontan Reservoir is an impoundment on the lower part of the Carson River; it was constructed in 1915 to store Carson and Truckee River waters for downstream irrigation.

2 Basin-fill deposits occur along small stream valleys in the Headwaters Area, but these deposits do not generally constitute aquifers of significant size. 
Studies of ground-water conditions in the Carson River basin include a reconnaissance-level survey of the water resources of the entire basin (Glancy and Katzer, 1975) and a number of other investigations that have focused mostly on individual hydrographic areas (figure 2). The hydrogeologic framework and hydrology of basin-fill aquifers have been described for Carson Valley (Piper, 1969; Maurer, 1985 and 1986), Eagle Valley (Worts and Malmberg, 1966; Arteaga, 1982), Stagecoach Valley (Harrill and others, 1984), and Carson Desert (Olmsted and others, 1984; Glancy, 1986). Three of the investigations in Carson (Maurer, 1986), Eagle (Arteaga, 1982), and Stagecoach Valleys, (J. R. Harril1, U.S. Geological Survey, written communication, 1986) include digital models of ground-water flow.

\section{Socioeconomic Setting}

The Carson River basin is a mostly rural setting in which cities with populations that range from a few hundred to a few tens of thousands are widely scattered. The principal towns and cities, in downstream order through the basin, are Markleeville, Calif., and Gardnerville, Minden, Carson City, Dayton, Virginia City, and Fallon, Nev. (figure 1). The two largest cities are Carson City and Fallon, with populations as of 1985 of 35,400 and 5,000, respectively (U.S. Bureau of the Census, written communication, 1986). The population of the entire Carson River basin in 1985 was about 70,000. Figure 4 shows that the population of the basin and adjacent areas, especially the Nevada parts, have increased dramatically since about 1950. This trend is expected to continue for several reasons. The area is popular for gaming and recreational activities, especially around Lake Tahoe and Reno. Many of the people directly employed in these two areas live in communities in the Carson River basin. In recent years, Nevada has been trying to develop an economy less dependent on gaming; consequently, a number of firms, mostly engaged in light industry, have located in the area. Finally, the area is considered to be a desirable place to live because of the relatively mild climate, scenic open spaces, and abundant recreational opportunities.

Historic land uses in the Carson River basin have centered around mining and agriculture. Although these historic uses are still important, urban and suburban development are rapidly increasing, sometimes at the expense of mining and agriculture. The 1-acre or larger rural lot has become popular, and populations outside cities are rapidly growing along the margins and lowlands of Carson Valley, in suburban areas of Eagle Valley, in the Carson Plains, Stagecoach Valley, Churchill Valley, and in lowlands adjacent to Fallon. These rural lands are commonly developed at the expense of agriculture, and development has directly conflicted with mining activities in the Virginia City area. Light industry also is expanding in the study area, mostly near Minden and Gardnerville in Carson Valley and in the Carson City urban area. This industry includes manufacturing operations for reinforced plastics, electronics, and computer components. 


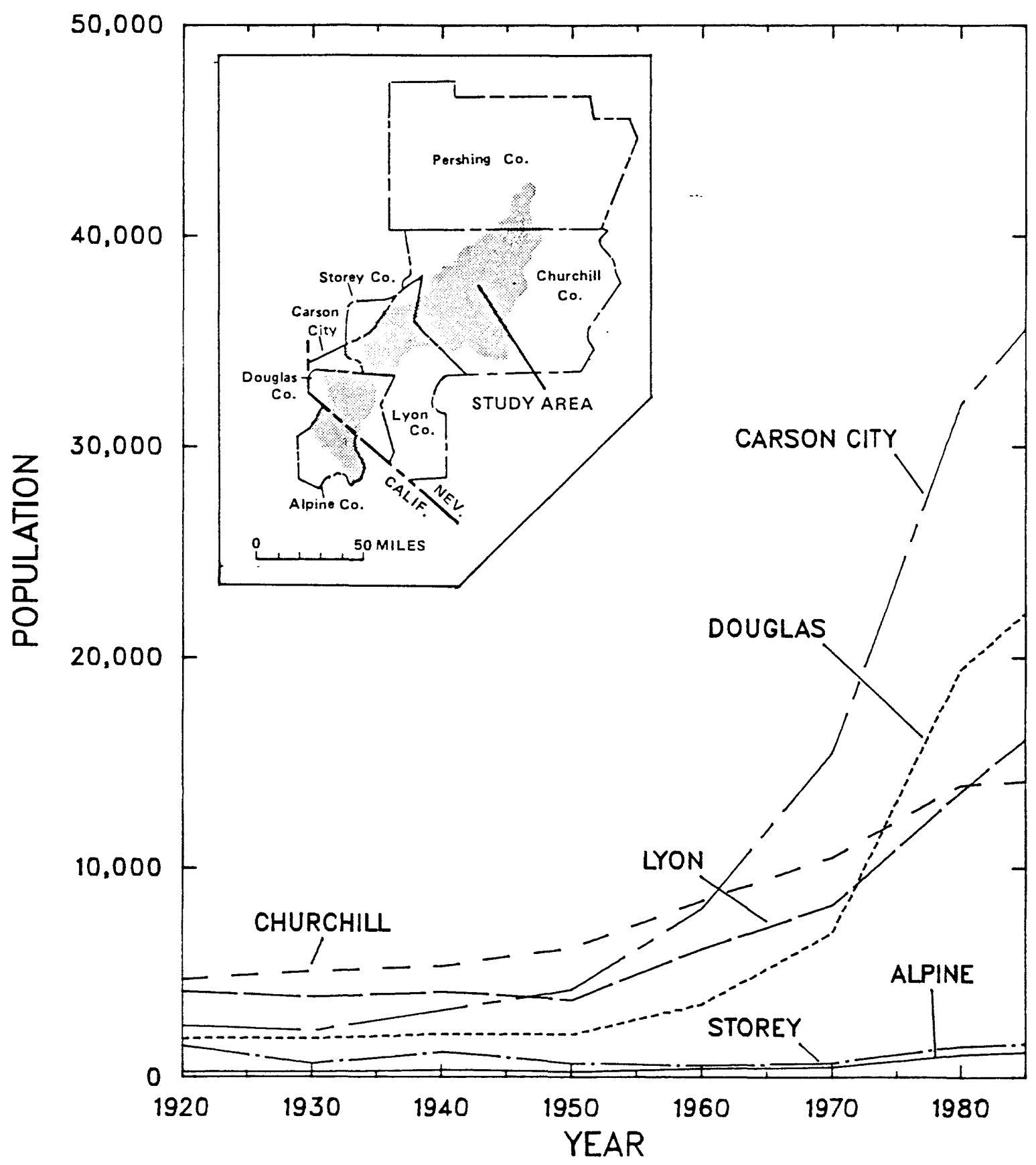

FIGURE 4.--Total population for Counties in the study area, 1920-85. Data sources: 1920-80, U.S. Bureau of the Census, 1922, 1952a, 1952b, 1983; 1985, U.S. Bureau of the Census, written communication, 1986. Data for Pershing County are not shown because that part of the County in study area is virtually unpopulated. 
Both surface- and ground-water resources are used to meet water needs in the Carson River basin. Water use in 1985 was an estimated 670,000 acrefeet, of which 97 percent was surface water (mostly flood irrigation in Carson Valley and Carson Desert) and 3 percent was ground water (E. A. Frick, U.S. Geological Survey, oral communication, 1986). Municipal and selfsupplied domestic uses accounted for about 14,000 acre-feet of water use in 1985, of which 9 percent was surface water and 91 percent was ground water.

\section{DESCRIPTION OF GROUND-WATER QUALITY ASSESSMENT PROJECT}

\section{Need for Water-Quality Assessment}

To date, no comprehensive analysis of water quality in the aquifers of the Carson River basin has been made. A wide range of information exists on chemistry, geology, hydrology, and land use, but it has not been assembled into a unified interpretive report. The available chemical data are not distributed so that the entire resource can be evaluated. In addition, these data are not adequate to assess the impacts of recent urban, suburban, and industrial expansion. Many man-made chemical substances, which may threaten the aquifers today, did not exist when water-quality sampling was begun, and little information exists for many of these substances.

It is necessary, therefore, to obtain new information on the Carson River basin aquifers. Perhaps the most pressing needs for additional data are those that address, at least partly, the water-quality issues defined in the following section and that also avoid the problems associated with historical data.

\section{Water-Quality Issues}

Several water-resources issues are of concern to officials of local, State, and Federal governments and to private citizens in the Carson River basin. These issues have historically centered around sources and availability of surface- and ground-water supplies. However, water-quality issues have begun to receive more attention because of general concern over the potential for contamination of drinking-water supplies. Some of the principal water-quality issues in the Carson River basin are listed below:

1. Trace elements in ground water, including arsenic, selenium, uranium, lithium, molybdenum, nitrate, flouride, and boron, are of concern throughout the Carson River basin. Concentrations of some of these constituents locally exceed drinking-water standards and seem to be particularly high in shallow aquifers that are recharged by flood irrigation. These problems have limited the utility of ground-water supplies and have caused some small private water companies in western Nevada to go out of business. In addition, boron concentrations may be affecting agricultural production in some areas. 
2. Land application is becoming the principal method of disposal of treated sewage effluent in Carson and Eagle Valleys. The effluent originates at treatment plants in Carson City and Gardnerville and also is imported into Carson Valley by pipeline from three plants in the Tahoe Basin. Concern exists as to the potential for this effluent to increase nitrate concentrations of ground water.

3. Geothermal resources are being exploited and developed in parts of the Carson River basin. Geothermal waters, under natural conditions, are a source of trace elements that can adversely affect ground-water quality for beneficial uses (01msted and others, 1984; Morgan, 1982); development of these resources could result in further contamination of ground water.

4. Radon gas, a product of the radioactive decay of uranium, may be present at elevated concentrations in ground water in parts of the Carson River basin, especially in ground water from recharge areas underlain by granitic or volcanic rocks.

5. Mine drainage and weathering of mineralized mine and mill tailings on the east fork of the Carson River have affected surface-water quality (trace elements, iron, lowered $\mathrm{pH}$ ) in that area (Ball and Nordstrom, 1985). In addition, reaches of the Carson River below Eagle Valley have high concentrations of mercury both in the river and in sediments of the stream bed (Van Denburgh, 1973; Cooper and others, 1985). Sources of this mercury are mine and mill tailings that were produced during the Comstock era (1859 to early 1900's, Stoddard and Carpenter, 1950, pages 15 and 22). Although this mercury or weathering of mine or mill tailings may be capable of contaminating ground water in the Carson Plains and downstream areas, there is no evidence as yet of such contamination.

6. Flood irrigation tends to flush soluble constituents from soils and can result in salinity problems in underlying shallow aquifers. In addition, irrigation waters can result in an increase of sodium in soils. Both of these potential problems are of concern in parts of the Carson River basin with shallow water levels.

7. In the past few years, small amounts of potentially hazardous organic compounds have been spilled in the Carson River basin. This problem may become more serious with increasing development of light industry in the area.

8. Underground storage tanks are common in all urban areas, and gasoline from such tanks may have contaminated shallow ground water in some areas of the Carson River basin. 


\section{Status of Water-Quality Knowledge}

The quality of ground water in the Carson River basin has been documented to a limited extent throughout the basin by Glancy and Katzer (1975) and by investigations of individual hydrographic areas or parts of them including Carson Valley (Spane, 1977), Eagle Valley (Trexler and others, 1980; Szecsody, 1982), Stagecoach Valley (Harrill and others, 1984) and parts of the Carson Desert (Olmsted and others, 1984; Glancy, 1986; Lico and others, 1986; Welch and Lico, 1986). These investigations describe ground-water quality to differing degrees. The data usually are limited to major cations and anions and do not deal with organic, trace-element, isotope, or radionuclide chemistry. The only exceptions are environmental isotope studies by Szecody (1982) and Harrill and others (1984), geochemical studies of geothermal systems (Trexler and others, 1980; 01msted and others, 1984 ), and studies of trace elements such as arsenic and selenium (Lico and others, 1986; Welch and Lico, 1986).

In addition to published sources of water-quality data cited above, extensive files of unpublished data are maintained by several Federal and State agencies and by the University of Nevada. Federal agencies that maintain water-quality data include the Geological Survey, Environmental Protection Agency, and the Bureau of Land Management. State agencies include the Nevada Division of Environmental Protection, Nevada Bureau of Mines and Geology, and Consumer Health Protection Service. The Desert Research Institute and the College of Agriculture, both part of the University of Nevada, also maintain files of water-quality data.

These unpublished water-quality data represent a potentially useful source of information for the Carson River basin NAWQA project. However, some of the data have limitations that severely restrict their utility for regional characterization of ground-water quality. One limitation is that most of the data include only the major cations and anions with few or no data for most trace inorganic and organic constituents. The utility of the data is also limited by uncertainties regarding well location, well construction, and sampling methodologies. In addition, inconsistencies in analytical methods and reporting conventions among the different laboratories represented makes interpretation of the existing data difficult. Finally, many existing wells do not provide opportunities for obtaining representative samples of the source aquifers either because the annular space around the casing may be improperly sealed and admit contaminants or because many pumps leak oil. In either case, the quality of water in the well can be affected without much effect on water in the surrounding aquifer. Such data are of questionable value for the purpose of characterizing regional ground-water quality. Despite these limitations, several different screening methods will be used to produce a reasonably reliable set of data that, along with published data, will be useful for a preliminary assessment of regional ground-water quality and for directing future work. 
In addition to water-quality data, other supplemental information is needed to interpret the water-quality data, including information on chemical and physical properties of soils and shallow-aquifer materials, and historic and current land uses. The former will be helpful for understanding relations between ground-water quality and the chemistry of aquifers and soils; the latter will be useful for delineating areas of potential ground-water contamination and for relating shallow ground-water quality to land-use practices.

\section{Study Approach}

The NAWQA program is a new undertaking of the Geological Survey. The organization of such an effort is complex because of the large areas involved, the high cost of field work and laboratory analyses, the large number of water-quality constituents of concern, and the high degree of spatial and temporal variability of ground-water quality. Each project must address water quality on a national scale, yet also must be responsive to the particular ground-water quality problems of the project area.

Thus, certain strategic choices have been made in designing the ground-water NAWQA projects. Each project will address only widespread water-quality problems. The projects are not designed to locate and describe individual cases of point-source contamination, although some individual contaminant plumes and localized contamination problems may be identified. The projects will emphasize regional degradation of groundwater quality such as might occur from nonpoint sources of pollution or from a high density of point sources. In order to use efficiently the available financial resources, the projects will use existing data whenever possible. Data available in published reports for factors such as land use, soil types, pesticide application, and cultivated acreage will be used. However, where available water-quality data are insufficient to conduct a water-quality assessment, additional sampling and chemical analyses will be required.

A survey of ground-water quality will be conducted for each groundwater project in order to obtain nationally consistent data on a wide range of water-quality constituents. The results of the surveys will be compiled into a comprehensive national data base so that ground-water quality among a11 the NAWQA ground-water projects can be compared. These data will be supplemented by sampling programs that address water-quality issues of particular concern within each study unit. The survey phase is referred to as the regional survey and the study-unit sampling programs are referred to as the topical studies. 
The quality of ground water in the Carson River basin will be investigated within the framework of the national program just described. The project will consist of three principal phases that will overlap to a limited extent. The first will consist of an analysis of existing data during the first full year (fiscal year 1987) of the project. The second and third will consist of the regional survey and topical studies, respectively, and both will span fiscal years 1987 through 1990. In addition, the project will involve coordination with local agencies and individuals, quality assurance, and management of the large body of data that are compiled and generated during the project. These six parts of the project are described below.

\section{Compilation and Analysis of Existing Data}

The first phase of the Carșon River basin project will be to compile and analyze several different types of data. The overall goal will be to describe regional ground-water quality in the Carson River basin as it presently can be understood by use of published and unpublished data and to relate that quality to past and present land uses and to hydrogeologic factors. This phase of the project will provide a limited perspective of regional ground-water quality in the basin, but will be useful as an initial analysis and for directing work during the second two phases of the project.

Water-quality data from sources described earlier will be used for this part of the study. The data will be reviewed to minimize potential problems defined earlier, particularly those of unpublished data. This process will consist of verifying site locations and sampling and analytical procedures. If a location cannot be verified, then the data will not be used. If either of the two procedures cannot be determined, the data will be used, but only for general descriptive purposes.

Available land-use and hydrogeologic data also will be used during the first part of the project. Land-use data for the Carson River basin have been compiled from aerial photographs taken from 1973 to 1979 on 1:250,000scale maps. Comparison of these land-use data to ground-water quality will provide a means, early in the project, of identifying areas where ground water may be contaminated.

Many questions will remain unanswered after existing data are compiled and analyzed. For instance, water quality will not be defined basin wide and usually will be represented by only a narrow range of constituents in those areas where it is defined. Land uses will be updated, especially in terms of recent urban and industrial development. Hydrogeologic data, especially chemical and physical properties of soils and shallow aquifer materials, are needed before relations between hydrogeology and ground-water quality can be determined. An anticipated outcome of this part of the project is a clearer understanding of what needs to be done to accomplish the overall project objectives. 


\section{Regional Surveys}

The second phase of the project will be a regional survey of groundwater quality designed to produce a data base for a wide range of inorganic constituents, synthetic organic compounds, and radionuclides in ground water. These data from all the pilot projects will be used to produce a nationally consistent data base. The surveys are needed because existing data usually have been collected to study specific problem areas and are generally inadequate to characterize the overall ground-water quality of the Nation, or even an individual region. In particular, data are sparse for potentially toxic trace elements and synthetic organic compounds other than those data collected to describe specific instances of actual or suspected point-source contamination.

Samples collected during the regional surveys for all ground-water projects will be analyzed for the same set of constituents by using consistent laboratory analytical protocols. Selection of constituents will emphasize those with potential human-health effects. They will include a suite of common inorganic constituents to describe the geochemical environment of the water samples, a suite of trace elements and radionuclides, and a broad range of pesticides and other synthetic organic compounds.

The overall goal of the regional survey will be to broadly characterize the quality of ground water in the Carson River basin with emphasis on developed areas. In order to achieve this goal, samples will be taken from shallow ground water at or near the water table, and from deeper aquifers, public water supplies, and domestic wells in rural areas. These four categories of sample locations will overlap; for instance, samples from public water supplies will almost always represent deeper aquifers, whereas samples from domestic wells may represent either shallow or deeper ground water. Samples of shallow ground water will be collected from properly constructed and documented existing wells or from new wells. The samples of deeper ground water will be collected mostly from public-supply and agricultural wells.

Water-quality data collected as a part of the regional survey will be used to: (1) determine the regional distribution of a wide range of potentially toxic constituents in ground water of the Carson River basin, (2) identify chemical constituents causing widespread water-quality problems in the aquifers and to locate problem areas, and (3) make statistical comparisons between water quality, hydrogeology, and land use.

As a part of a separate project, the Geological Survey will collect soil chemistry data throughout the Carson River basin. At coincident locations in the two sampling networks, a geochemical analysis of surficial soils and shallow aquifer materials as well as an analysis of ground water will be made. The soil survey will provide a broader areal coverage of the entire basin than the water-quality survey, and the resulting data may be a useful source of hydrogeologic information for the NAWQA project. 


\section{Topical Studies}

The regional survey is expected to yield a broad, but limited, description of the areal distribution of ground-water quality within the Carson River basin. The project area has unique characteristics and problems that need to be addressed within the context of a national assessment. Therefore, the topical studies will focus on water-quality issues of particular concern within the project area.

Each of the studies will involve a limited set of constituents and may focus on either the entire project area or a part of it that is of particular concern. The results of the regional survey probably will be a useful guide for identifying areas suitable for topical studies. These studies will be designed to provide more detailed spatial characterizations of selected substances that affect the beneficial uses of ground water and that are widespread in the project area. Information on geology, hydrology, and geochemical processes will be used to formulate hypotheses that are tested by a sampling program. Many, if not all, of the sample sites for each of the topical studies will be shallow wells. Existing wells will be used where appropriate, but additional wells may be drilled for each of the studies.

Some of the principal water-quality issues in the Carson River basin that may develop into topical studies include the basin-wide occurrence of trace constituents in ground water and soils, the effects of flood irrigation on the mobilization of trace constituents, radionuclides in ground water, the fate of pesticides in agricultural areas, and the potential for contamination of ground water by man-made organic compounds in urban and industrial areas. This list is not all inclusive and may change during the course of the project. In addition, limited resources will restrict the number of topical studies that can be made as a part of this project.

Trace elements may be widespread in soils and ground water in the Carson River basin. Near Fallon in the Carson Desert, arsenic concentrations in soils and shallow ground water have been investigated at two flood-irrigated fields (Lico and others, 1986; Welch and Lico, 1986) and in deeper ground water (Glancy, 1986). Trace constituents in ground water have also been identified in other parts of the project area; in spite of these investigations, however, the occurrence of trace constituents is poorly understood. One or more intensive studies will be made in order to better understand the conditions under which trace constituents are mobilized and enter ground water. Probable objectives of these studies would be to investigate relations between concentrations of these constituents in soils and shallow ground water and the effects of flood irrigation. A possible approach might be to select small study plots of irrigated and nonirrigated lands in the Carson Desert and, if appropriate, Carson Valley. 
The source of radon in ground water is believed to be uranium in granitic and volcanic rocks, both of which are widespread in the Carson River basin. High concentrations of radon (more than 5,000 picocuries per liter) detected in several samples of ground water in Carson Valley seem to be related to nearby granitic rocks. Extensive recharge areas of granitic rocks on the west sides of both Carson and Eagle Valleys suggest that radon may be present in ground water in these areas. Samples of ground water taken as part of the regional survey will be analyzed for radon; based on results of the survey, more intensive studies may be made to identify recharge areas that are sources of this element.

Pesticides are used for agricultural purposes in Carson Valley and in the Carson Desert. In spite of this use, published reports on the extent of their presence in ground water are not available. Known areas of pesticide application in either or both of the valleys may be selected for further study to determine the fate of these compounds after application.

Storage tanks for petroleum products are potential sources of ground-water contamination because of leaks from some older underground tanks. Carson City may be a good site for an investigation of this type of contamination because several tanks at gasoline service stations in the downtown area were found to be leaking several years ago. These tanks were replaced and others that were not leaking are being monitored for leaks. Thus, there is potential not only for defining the extent of the contamination, but also for studying its behavior in the ground-water system over the long term.

A possible topical study not directly related to any of the waterquality issues listed earlier is that of developing a better understanding of recharge processes. Ages of water may be determined along ground-water flow paths as a part of the regional survey. The results may then be used to identify one or more areas where intensive age dating of ground water will be done. Based on the results of these more intensive studies and on an improved understanding of geology and hydrology, it may be possible to identify broad areas where recharge can transport contaminants introduced at land surface to shallow ground water. 
Coordination between the Geological Survey and officlals of local, State, and Federal government; other scientists; and interested private citizens is an important part of the NAWQA program. Therefore, each pilot project will have a liaison committee to help ensure that local needs and issues are addressed by the study. The committee will act in an advisory capacity and its input will be useful for identifying water-quality constituents and study locations of local and regional interest and for reviewing draft reports produced by the study. The liaison committee for the Carson River basin NAWQA consists of the following organizations:

California Department of Water Resources

California Lahontan Regional Water Quality Control Board

City of Fallon

Doug las County Department of Public Works

Fallon Paiute-Shoshone Tribes

Nevada Bureau of Mines and Geology

Nevada Consumer Health Protection Service

Nevada Division of Environmental Protection

Nevada Division of Water Resources

U.S. Bureau of Land Management

U.S. Bureau of Reclamation

U.S. Environmental Protection Agency, Region IX Office of Ground Water

University of Nevada

College of Agriculture

Desert Research Institute

In addition to the local liaison committees, a National Coordinating Work Group has been established to advise the Geological Survey on the coordination of the NAWQA program. The work group functions under the general auspices of the Interagency Advisory Committee on Water Data and the Advisory Committee on Water Data for Public Use. The general purposes of the work group are to advise the Geological Survey on (1) water-quality information needs of non-Federal and Federal communities of water users and (2) procedures for providing appropriate and timely release of data and other results of the study. The work group currently consists of the Chief Hydrologist of the Geological Survey and representatives from other Federal and non-Federal agencies and organizations, including the pilot project liaison committees. Organizations and agencies represented include: American Water Resources Association, Association of American State Geologists, Association of State and Interstate Water Pollution Control Administrators, Chemical Manufacturers Association, Interstate Conference on Water Programs, National Association of Conservation Districts, U.S. Army Corps of Engineers, U.S. Bureau of Reclamation, Council on Environmental Quality, U.S. Environmental Protection Agency, U.S. Fish and Wildlife Service, U.S. Forest Service, and U.S. Soil Conservation Service. 


\section{Quality Assurance}

Variability in analytical results, caused by errors in the samplecollection and analysis processes, always occurs even under rigorously controlled field and laboratory conditions. For example, errors can be introduced into sample results through (1) selection of a sampling location or method that produces a sample that fails to represent the conditions of interest, (2) improper use of instruments, (3) contamination of the sample, and (4) inappropriate methods of analysis. These errors can be so small that they cannot be measured, or so large that their presence is obvious. Quality-assurance programs are used to detect and control these errors and to maintain and document the reliability of results.

A technical quality-assurance plan is being prepared for the NAWQA program. This plan will address all aspects of sample collection, analysis, and reporting needed to produce reliable and verifiable data in a nationally consistent manner. The plan probably will draw heavily upon existing Geological Survey quality-assurance policies and procedures described in manuals by the Office of Water Data Coordination (1977) and by Friedman and Erdmann (1983).

\section{Data Management}

One of the major tasks of the NAWQA project will be to store, retrieve, and manipulate large amounts of chemical and geographic information. The National Water Information System (NWIS) will be the primary repository of well information and chemical data. Land-use and other geographic information will be stored and manipulated in a geographic information system (GIS) using ARC/INFO software. 1

NWIS has been developed over many years by the U.S. Geological Survey and offers the capability of storing and accessing large amounts of chemical data and well information. It has the advantages that it is an established system, is widely accessible, and is merged periodically with the STORET data base maintained by the U.S. Environmental Protection Agency.

ARC/INFO is a powerful geographic information package that will be used for developing maps and studying the geographical relations among the various types of data. It operates on point, line, and polygon data and is extremely useful in subsetting, displaying, and mapping data. This technology will be used in the Carson River basin NAWQA project to test hypotheses about the spatial distribution of water-quality data and to produce graphical report products.

1 The use of trade names in this report is for descriptive purposes only and does not constitute an endorsement by the U.S. Geological Survey. 


\section{SUMMARY}

In April 1986, the U.S. Geological Survey began a program for defining the Nation's regional water quality. The program, known as the National Water Quality Assessment program, is in its early stages and consists of a pilot program of four surface-water and three ground-water projects. One of the pilot projects will consist of an evaluation of regional ground-water quality in the Carson River basin of western Nevada and eastern California. This report describes ( 1 ) the goals and objectives of the national program and the Carson River basin NAWQA project, (2) the project area and its associated water-quality issues, and (3) a study approach for the project.

The emphasis of the National Water Quality Assessment Program will be that of characterizing regional water quality with respect to a broad range of constituents including inorganic, organic, and radionuclide chemistry. The objectives of the Carson River basin project are to: (1) define regional ground-water quality throughout the basin; (2) describe relations between shallow ground-water quality, chemical and physical properties of soils and aquifer materials, and current and past land uses; (3) provide a general description of the location, nature, and possible causes of selected widespread water-quality problems within the project area; and (4) develop new techniques for characterizing regional ground-water quality, especially in arid alluvial basins.

The Carson River basin consists of a Headwaters Area and six alluvial valleys that are interconnected by the Carson River. Ground water in each valley is stored within basin-fill deposits (clay, silt, sand, and grave1) that have accumulated in the deep bedrock basin that underlies each valley. Aquifers within each valley generally consist of a shallow water-table aquifer that is underlain by one or more deeper confined aquifers. The shallow aquifers and the river are hydraulically connected to differing degrees.

The population of the Carson River basin was about 70,000 in 1985 and is increasing rapidly because of the growth of the gaming industry, an influx of light industry, and because the area is considered a desirable place to live. Water-quality issues in the basin are principally related to concern over potential contamination of drinking-water supplies and the rapid urban, suburban, and industrial growth in the area. Existing information, in the form of previous investigations and files of unpublished data maintained by several State and Federal agencies and universities, are probably not sufficient for characterizing the regional quality of ground water in the Carson River basin because most of the analytical data are for the more common chemical constituents of water. In addition, some of the unpublished data may be unsuitable because well locations and construction methods are not always adequately documented, and inappropriate sampling techniques may have been used. In spite of these drawbacks, the unpublished data can be reviewed and, along with published data, used to describe areal and vertical variations in concentration of some constituents in order to guide further sampling. 
Additional data that are needed to accomplish the project objectives are: (1) reliable and detailed water-quality data that address the principal water-quality concerns in the basin; (2) hydrogeologic data, including chemical and physical properties of soils and aquifer materials; and

(3) current and historic land-use data.

The project will consist of three principal phases--compilation and analysis of existing data, a regional water-quality survey of a wide range of substances, and topical studies that address selected water-quality issues. During the first full year of the project (fiscal year 1987), existing data will be obtained and reviewed in order to define ground-water quality as it is presently understood and to provide guidance for further sampling. These data will also constitute the beginnings of a water-quality data base for the Carson River basin.

The second phase will begin during the first full year of the project and will consist of a regional survey of ground-water quality in the Carson River basin. Sites will be located to sample shallow ground water at or near the water table from properly documented existing wells and from new wells. Deeper ground water also will be sampled, mostly from public watersupply and agricultural wells. In addition, samples will be collected at domestic wells in rural areas. These samples will provide a consistent set of data that can be used to characterize regional quality of ground water in the Carson River basin and to compare water quality with other aquifers in the Nation.

The third phase of the project will be topical studies. The emphasis of these studies will be to characterize water quality in the Carson River basin with respect to certain constituents, either basin wide or within specific areas of concern. This part of the project will address, in more detail than the regional survey, some of the principal water-quality issues in the basin. Potential topics include the basin-wide occurrence of trace constituents, the effects of flood irrigation on mobilization of these constituents, presence and sources of radionuclides in ground water, the fate of pesticides in agricultural areas, the potential for contamination of ground water by synthetic organic compounds, and recharge processes.

In addition, the project will include three additional aspects. The first will be to coordinate project activities with a local liaison committee that represents local, State, and Federal Government in the Carson River basin. The second will be to assure that consistent methods are used to acquire data. The third will be to develop a data base so that the data compiled and produced during the project are readily available after the project is completed. 
Arteaga, F. E., 1982, Mathematical model analysis of the Eagle Valley ground-water basin, west-central Nevada: 'U.S. Geological Survey Open-File Report 80-1224, 55 p.

Association of State and Interstate Water Pollution Control Administrators, 1984, America's clean water--The States' evaluation of progress, 1972-1982: $16 \mathrm{p}$.

Bal1, J. W., and Nordstrom, D. K., 1985, Major and trace-element analyses of acid mine waters in the Leviathan Mine drainage basin, Californial Nevada, October 1982: U.S. Geological Survey Water-Resources Investigations Report $85-4169,46 \mathrm{p}$.

Brown, W. M., III, Nowlin, J. O., Smith, L. H., and Flint, M. R., 1986, River-quality assessment of the Truckee and Carson river system, California and Nevada--hydrologic characteristics: U.S. Geological Survey Open-File Report 84-576, 201 p.

Cooper, J. J., Thomas, R. O., and Reed, S. M., 1985, Total mercury in sediment, water, and fishes in the Carson River drainage, west-central Nevada: Nevada Division of Environmental Protection, 96 p.

Friedman, L. C., and Erdmann, D. E., 1983, Quality assurance practices for the chemical and biological analyses of water and fluvial sediments: U.S. Geological Survey Techniques of Water-Resources Investigations, Book 5, Chapter A6, $181 \mathrm{p}$.

Glancy, P. A., 1986, Geohydrology of the basalt and unconsolidated sedimentary aquifers in the Fallon area, Churchill County, Nevada: U.S. Geological Survey Water-Supply Paper 2263, 62 p.

Glancy, P. A., and Katzer, T. L., 1975, Water-resources appraisal of the Carson River basin, western Nevada: Nevada Division of Water Resources, Reconnaissance Report 59, 126 p.

Harrill, J. R., Welch, A. H., and Preissler, A. M., 1984, Hydrogeologic controls on ground-water flow in Stagecoach Valley, Nevada: $97 \mathrm{th}$ Annual Meeting, Geological Society of America, Reno, Nev., November 1984, Field-Trip Guidebook, p. 117-120.

Jennings, C. W., compiler, 1977, Geologic map of California: California Division of Mines and Geology Geologic Data Map 2, scale 1:750,000. 
Lico, M. S., Welch, A. H., and Hughes, J. L., 1986, Hydrologic, 1ithologic, and chemical data for sediment in the shallow alluvial aquifer at two sites near Fallon, Churchill County, Nevada, 1984-85: U.S. Geological Survey Open-File Report 86-250, 43 p.

Maurer, D. K., 1985, Gravity survey and depth to bedrock in Carson Valley, Nevada-California: U.S. Geological Survey Water-Resources Investigations Report 84-4202, 20 p.

----1986, Geohydrology and simulated response to ground-water pumping in Carson Valley, a river-dominated basin in Douglas County, Nevada, and Alpine County, California: Water-Resources Investigations Report $86-4328,109 \mathrm{p}$.

Morgan, D. S., 1982, Hydrogeology of the Stillwater area, Churchill County, Nevada: U.S. Geological Survey Open-File Report 82-345, 95 p.

Morrison, R. B., 1964, Lake Lahontan--Geology of southern Carson Desert, Nevada: U.S. Geological Survey Professional Paper 401, 156 p.

Office of Water Data Coordination, 1977, National handbook of recommended methods for water-data acquisition: U.S. Geological Survey, 872 p.

01msted, F. H., Welch, A. H., Van Denburgh, A. S., and Ingebritzen, S. E., 1984, Geohydrology, aqueous geochemistry, and thermal regime of the Soda Lakes and Upsal Hog back geothermal systems, Churchill County, Nevada: U.S. Geological Survey Water-Resources Investigations Report $84-4054,166 \mathrm{p}$.

Piper, A. M., 1969, A water budget of the Carson Valley, Nevada: U.S. Geological Survey Professional Paper 417-F, 8 p.

Rush, F. E., 1968, Index of hydrographic areas in Nevada: Nevada Division of Water Resources Information Report 6, 38 p.

Spane, Frank, 1977, Evaluation of factors influencing the inorganic water-quality regimen of Carson River, Carson Valley, NevadaCalifornia: University of Nevada, Reno, unpublished $\mathrm{Ph}$. D. thesis, 206 p.

Stewart, J. H., 1980, Geology of Nevada--A discussion to accompany the geologic map of Nevada: Nevada Bureau of Mines and Geology Special Publication 4, 136 p.

Stewart, J. H., and Carlson, J. E., 1977, Geologic map of Nevada: Nevada Bureau of Mines and Geology Map 57, scale 1:1,000,000. 
Stoddard, Carl, and Carpenter, J. A., 1950, Mineral Resources of Storey and Lyon Counties, Nevada: University of Nevada Bulletin, Geology and Mining Series no. 49, 115 p.

Szecsody, J. E., 1982, Use of major ion chemistry and environmental isotopes to delineate subsurface flow in Eagle Valley, Nevada: University of Nevada, Reno, unpublished M.S. thesis, 195 p.

Trexler, D. T., Koenig, B. A., Flynn, Thomas, and Bruce, J. L., 1980, Assessment of geothermal resources of Carson-Eagle Valleys and Big Smoky Valley, Nevada--First annual report: Nevada Bureau of Mines and Geology Report DOE/NV/10039-2, 162 p.

U.S. Bureau of the Census, 1922, Population-1920, v. 3: Washington, D.C., U.S. Government Printing Office.

---1952a, Census of Population-1950, v. 2, part 5: Washington, D.C., U.S. Government Printing Office.

- - 1952b, Census of Population-1950, v. 2, part 28: Washington, D.C., U.S. Government Printing Office.

---1983, Census of Population-1980, v. 1, chapter A, part 1: Washington, D.C., U.S. Government Printing Office.

Van Denburgh, A. S., 1973, Mercury in the Carson and Truckee River basins of Nevada: U.S. Geological Survey open-file report, 12 p.

Welch, A. H., and Lico, M. S., 1986, Arsenic in shallow ground water beneath an irrigated pasture in western Nevada [abs.]: Transactions, American Geophysical Union, v. 67 , no. 44, p. 940.

Worts, G. F., Jr., and Malmberg, G. T., 1966, Hydrologic appraisal of Eagle Valley, Ormsby County, Nevada: Nevada Department of Conservation and Natural Resources, Water Resources - Reconnaissance Report 39, 55 p. 